\title{
QUADRATIC BOOST CONVERTER WITH CLD CELL FOR SOLAR LIGHTING APPLICATIONS
}

\author{
J. Arthur Vasanth \\ Assistant Professor, Department of Electrical and Electronics Engineering, \\ Bannari Amman Institute of Technology, Sathyamangalam, Tamil Nadu, India \\ T. Sathiyanarayanan \\ Assistant Professor, Department of Electrical and Electronics Engineering, \\ Bannari Amman Institute of Technology, Sathyamangalam, Tamil Nadu, India

\section{Siva Kumar} \\ PG Scholar, Department of Electrical and Electronics Engineering, \\ Bannari Amman Institute of Technology, Sathyamangalam, Tamil Nadu, India
}

\begin{abstract}
The dc-dc converter is necessary to boost the low voltage from Solar panel/array to required voltage in Solar PV applications. In Solar PV system, the dc-dc converter will be buck-boost or boost converter. Many new boost converters are derived nowadays. In these, one of the modern converters is quadratic boost converter. Boost converters are required to operate at high values of duty ratio to get higher output voltage levels. The drawback of higher duty ratio value is that it limits the switching frequency values due to high reverse recovery time, which leads to poor efficiency and high electromagnetic interference effects. In existing boost converters, the switches are suffered with high voltage stress. The proposed work has not considered the electromagnetic interference but rest of the issues are taken care by adding appropriate Capacitor, Inductor, Diode bridge (CLD) with the Quadratic boost converter. In this proposed converter high output voltage is obtained with low duty ratio. Thus, it eliminates the problem of high reverse recovery time and limitation in using high switching frequency. It also reveals that the efficiency of the quadratic boost converter with CLD cell is higher than conventional boost converters and voltage stress is drastically reduced for the same output. Therefore, quadratic boost converter with CLD cell is well suited for solar PV lighting applications.
\end{abstract}

Key words: CLD, Quadratic Boost Converter, Voltage Stress, Reverse Recovery time, EMI, DC-DC Converter

Cite this Article: J. Arthur Vasanth, T. Sathiyanarayanan and M. Siva Kumar, Quadratic Boost Converter with CLD Cell for Solar Lighting Applications, International Journal of Electrical Engineering and Technology (IJEET), 12(5), 2021, pp. 189-196.

https://iaeme.com/Home/issue/IJEET?Volume=12\&Issue $=5$ 


\section{INTRODUCTION}

In short span of time the average electricity per capita is increased drastically in worldwide due to the increased population and life style of the people. This results in high depletion of natural resources such as coal, oil and natural gas. Thereby, the future is mostly depending on the renewable energy sources. The solar PV panel gives a dc voltage with minimum magnitude. This low voltage from solar PV panel is to be increased to the sufficient level that required by the load and it can be done using dc-dc converters. Among many dc-dc converters the boost converter is adapted to boost the voltage levels from solar PV panel/array. Generally, the output voltage of dc-dc converter is directly proportional to the duty ratio up to certain high range say 0.7 or 0.8 and this range vary depends on the topology of the dc-dc converter. The problems in using high duty ratio are, it limits the switching frequency since the switching pulse with high duty ratio has minimum off time, poor efficiency and EMI. The voltage stress is also another issue in boost converter and that too directly proportional to the duty ratio. Though the high duty ratio offers high voltage gain it is impeding to use as it raises the above stated issues.

Many converters have been derived to achieve high voltage gain, efficiency, less voltage stress with minimum duty ratio. The ultra-step up DC-DC converter with reduced switching stress is proposed to get higher voltage transfer gain with reduced semiconductor voltage stress. This topology is analysed with ideal components and it suffers from pulsating input current. A high efficiency high step up DC-DC converters are proposed to achieve high step up voltage gain and voltage efficiency. Coupled inductor is used to provide high voltage gain and there will be efficiency degrading due to leakage inductor.

The identified problem for the proposed work is that the boost converters are operated at higher duty ratio to get maximum voltage gain. This high value of duty ratio limits the switching frequency and provides high voltage stress in the power electronic switch. Operating the converter with high duty ratio ultimately affect the efficiency and further increase the EMI generation. The objective of the proposed work in the paper is to attain high voltage gain in the converter with less duty ratio and reduces the limitation of high switching frequency and also, to decrease the voltage stress across the switching devices for improving efficiency.

\section{LITERATURE REVIEW}

J.A. Morales-Saldana [1] proposed a controller design method to the quadratic boost converter based on a single switch by current-programmed control scheme. The proposed control scheme works by sensing the current of the switch for feedback applications. The design based results points out the easy way of optimizing the converter's performance from the control circuit parameters.

Yuang Shung Lee [2] have suggested quadratic boost converter method for high conversion ratio along with an active zero-voltage switching (ZVS) snubber circuit is developed for PV applications. A front inductor is proposed to reboost the voltage gain to get high output voltages. Oswaldo Lopez-Santos [3] have made diligent comparison between the traditional boost converter and novel cubic boost converter. The author analyzed about the quadratic boost converter with high DC gain to boost the voltage of a normal photovoltaic panel up to $400 \mathrm{~V}$. A hysteretic comparator is employed to control saturation level at high duty ratio operation of converter. The output voltage is regulated using two loop sliding-mode control.

Jorge Alberto Morales-Saldaña [4] have presented a study on Reduced Redundant Power Processing (R2P2) principle based quadratic boost converter. The current programmed control is used for controller design to maintain the output voltage regulation. Yuan-mao Ye [5] have proposed a new quadratic boost converter with the traditional boost converter, where the proposed topology has benefits like low buffer capacitor voltage stress and high voltage gain so it can be used for applications operated with two LC filters and only one active switch. 
K.H.Beena [6] have explained about the quadratic boost converter in single switch mode. The proposed converter step up $18 \mathrm{~V}$ dc battery voltage to 70 volts output for a $50 \mathrm{~W}$ load by using a single switch. The exact mathematical model of converter gains and passive elements values are calculated theoretically using design equations. K.Tattiwong [7] have presents Quadratic Boost Converter (QBC) with mathematical expressions to analyse, design and implementation procedures.

\section{QUADRATIC BOOST CONVERTER WITH CLD CELL}

Quadratic boost converter with CLD cell in figure 3.1 is presented to overcome the problems in the traditional boost converter and also to improve the switching frequency and reduce the stress on the switches. The analysis is done by assuming all the devices of the quadratic boost converter with CLD cell are considered as ideal components. Assuming that the proposed converter operates in continuous conduction mode (CCM). The switching frequency of the proposed converter is higher than the natural frequency. The capacitor voltages and inductor currents are assumed as constant with small relative AC ripples, and the proposed quadratic boost converter with CLD circuit diagram is shown in figure 1.

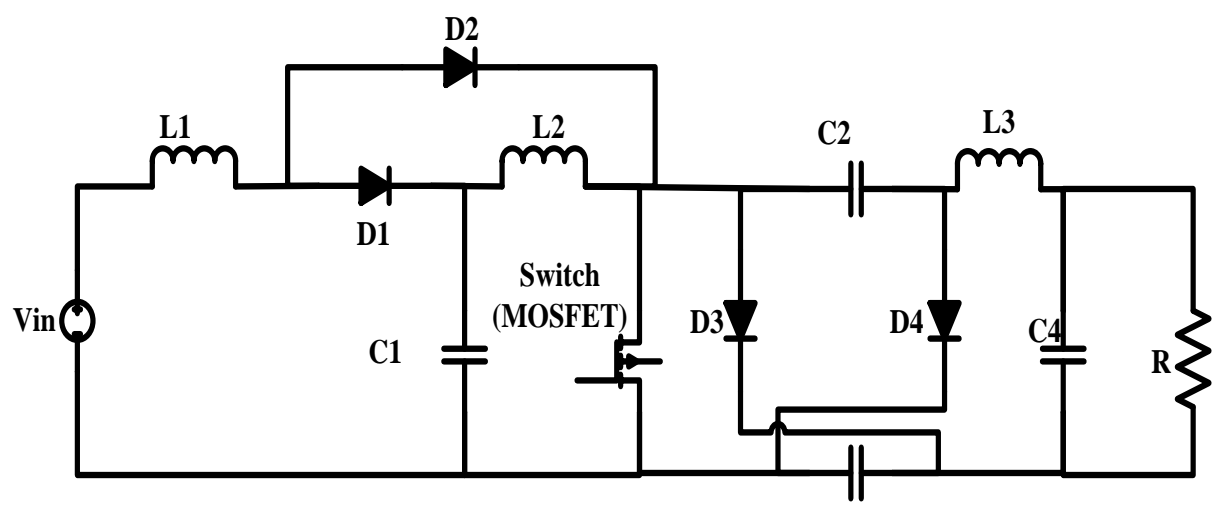

C3

Figure 1 Circuit Diagram of Quadratic Boost Converter with CLD cell

\subsection{Working Principle}

\section{Mode 1: When Switch is ON}

When the switch $\mathrm{S}$ is on then the input voltage source $\mathrm{V}_{\text {in }}$ delivers energy to inductor $\mathrm{L}_{1}$, while capacitor $C_{1}$ delivers its stored energy to inductor $L_{2}$, capacitor $C_{2}$ and $C_{3}$ discharge energy through the switch and inductor $\mathrm{L}_{3}$ stores that energy. Figure 2 shows the mode 1 operation of quadratic boost converter with CLD cell. Consequently, all of the inductor currents $i_{L 1}$, $i_{L 2}$ and $i_{\mathrm{L} 3}$ are linearly increasing in the mode 1 . The slopes of the inductor current $i_{L 1}, i_{L 2}$ and $i_{L 3}$ is given in equation 1 as,

$$
\frac{d i_{L_{1}}}{d t}=\frac{V_{S}}{L_{1}}, \frac{d i_{L_{2}}}{d t}=\frac{V_{C 1}}{L_{2}}, \frac{d i_{L_{3}}}{d t}=\frac{2 V_{C 2}-V_{O}}{L_{1}}
$$




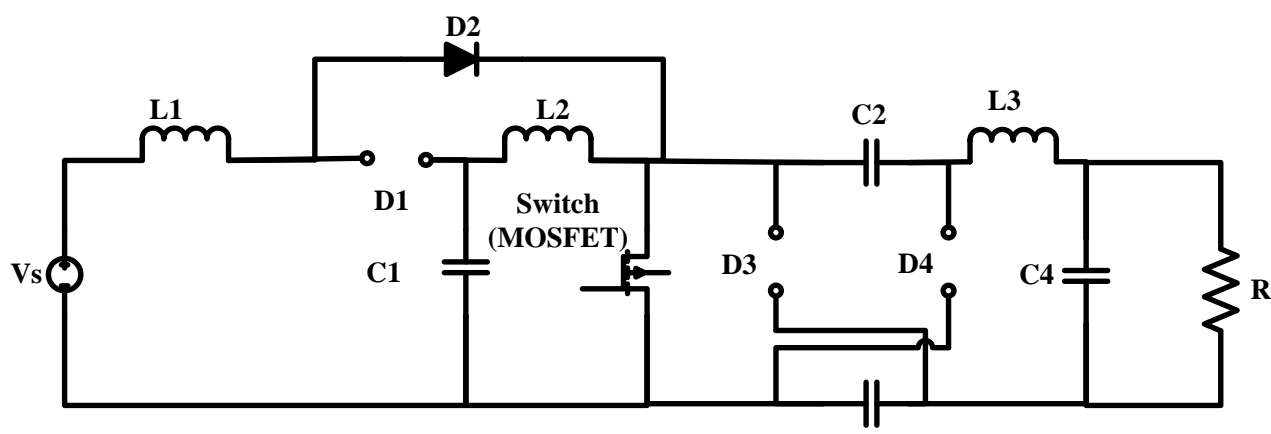

C3

Figure 2 Mode 1 Operation of Quadratic Boost Converter with CLD cell

\section{Mode 2: When Switch is OFF}

When $\mathrm{S}$ is OFF then the inductor $\mathrm{L}_{1}$ stored energy is delivered to $\mathrm{C}_{1}$ and the inductor $\mathrm{L}_{2}$ distributes the stored energy to $\mathrm{C}_{2}, \mathrm{C}_{3}$ and $\mathrm{R}$. The energy stored in the inductor $\mathrm{L}_{3}$ is brought out to the output. Therefore, all of the inductor currents $i_{L 1}, i_{L 2}$ and $i_{L 3}$ are decreasing linearly in the mode 2 . The mode 2 operation of the quadratic boost converter is shown in figure 3.

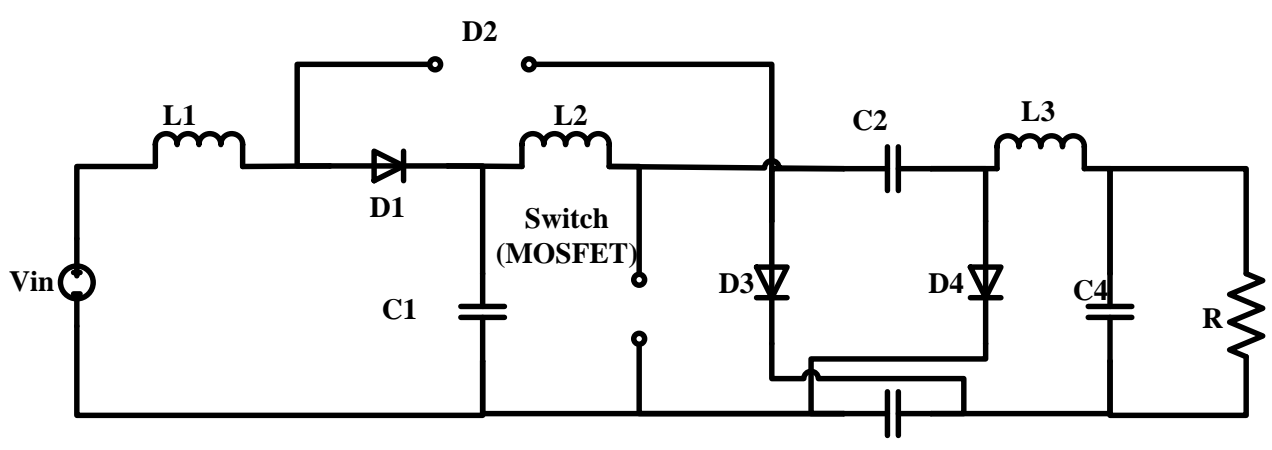

C3

Figure 3 Mode 2 Operation of Quadratic Boost Converter with CLD cell

\subsection{Output Equation of Quadratic Boost Converter with CLD Cell}

The slope of the inductor currents $i_{L 1}, i_{L 2}$ and $i_{L 3}$ during this period is given in equation 2.

$$
\frac{d i_{L_{1}}}{d t}=\frac{V_{S}-V_{C 1}}{L_{1}}, \frac{d i_{L_{2}}}{d t}=\frac{V_{C 1}-V_{C 2}}{L_{2}}, \frac{d i_{L_{3}}}{d t}=\frac{V_{C 2}-V_{O}}{L_{1}}
$$

From the figure 3.2 and 3.3, the voltage step up ratio $\mathrm{M}$ is calculated from the volt-second balance of inductors $\mathrm{L}_{1}, \mathrm{~L}_{2}$ and $\mathrm{L}_{3}$ is given in equations 3,4 and 5 respectively.

$$
\begin{array}{ll}
L_{1}: & V_{S} t_{O N}+\left(V_{S}-V_{C 1}\right) t_{O F F}=0 \\
L_{2}: & V_{C 1} t_{O N}+\left(V_{C 1}-V_{C 2}\right) t_{O F F}=0 \\
L_{3}: & \left(2 V_{C 2}-V_{O}\right) t_{O N}+\left(2 V_{C 2}-V_{O}\right) t_{O F F}=0
\end{array}
$$

From the equations (3) and (4), the step up ratio $M$ can be obtained from equation 6.

$$
M=\frac{V_{O}}{V_{S}}=\frac{(1+\delta)}{(1-\delta)^{2}}
$$

The output equation for the quadratic boost converter with CLD cell is given in equation 7 .

$$
V_{O}=V_{S} * \frac{(1+\delta)}{(1-\delta)^{2}}
$$




\section{SIMULATION RESULTS}

The inductor and capacitor values are found theoretically and it is used to simulate the quadratic boost converter with CLD cell using MATLAB/Simulink toolbox.

The simulation model of quadratic boost converter with CLD cell is shown in figure 4 . The CLD cell is used to smooth the switching stress of the switches by using its storage elements. This makes the converter operating for higher switching frequency levels. The values used in the simulation for the inductor and capacitors are $L_{1}=101 \mu \mathrm{H}, L_{2}=150 \mu \mathrm{H}, L_{3}=1667 \mu \mathrm{H}, C_{1}=$ $110 \mu \mathrm{F}, C_{2}=C_{3}=50 \mu \mathrm{F}, C_{4}=50 \mu \mathrm{F}$.

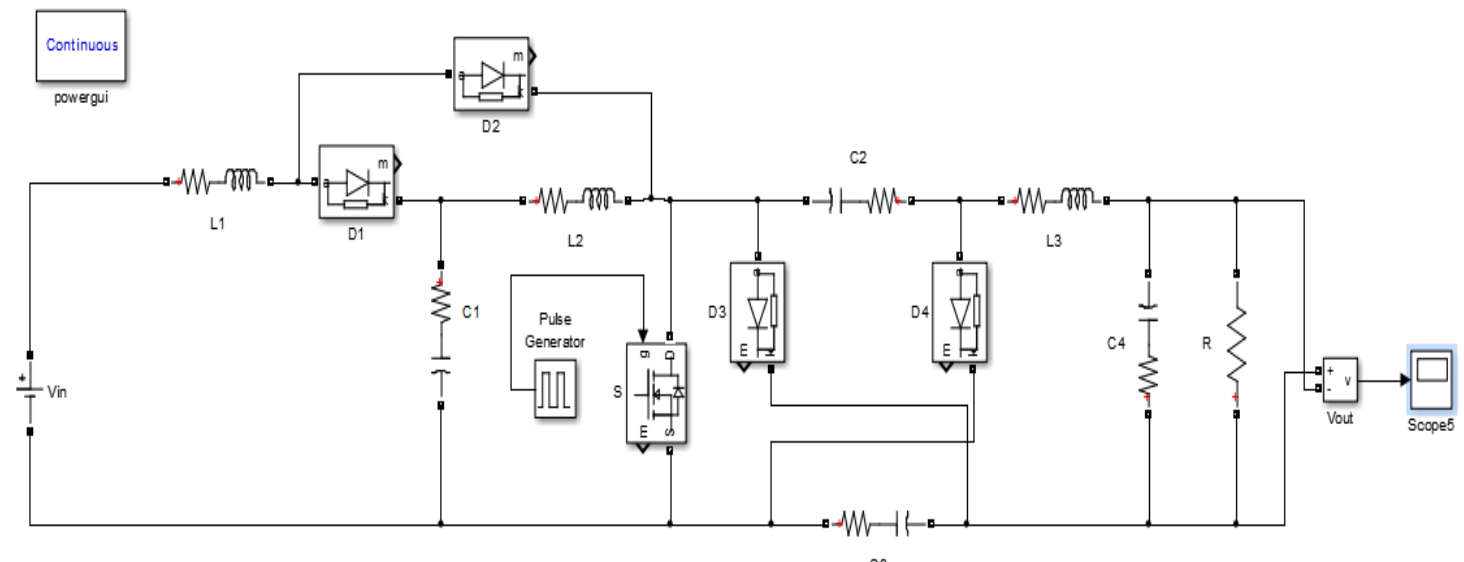

Figure 4 Simulation Circuit Diagram of Quadratic Boost Converter with CLD Cell

If $\delta=0.5, F_{S}=10 \mathrm{kHz}, V_{S}=10 \mathrm{~V}$ from the equation (7), $V_{O}=60 \mathrm{~V}$. The theoretical output voltage is $60 \mathrm{~V}$ whereas the simulation output voltage of quadratic boost converter with CLD cell is $57.7 \mathrm{~V}$ which is taken from the graph shown in figure 5. The table 1 shows the comparison of theoretical output voltage and simulation output voltage which also shows that the high output voltage gain is achieved in low duty ratio. The figure 6 gives the graphical representation of output voltage of the converter for each duty ratios.

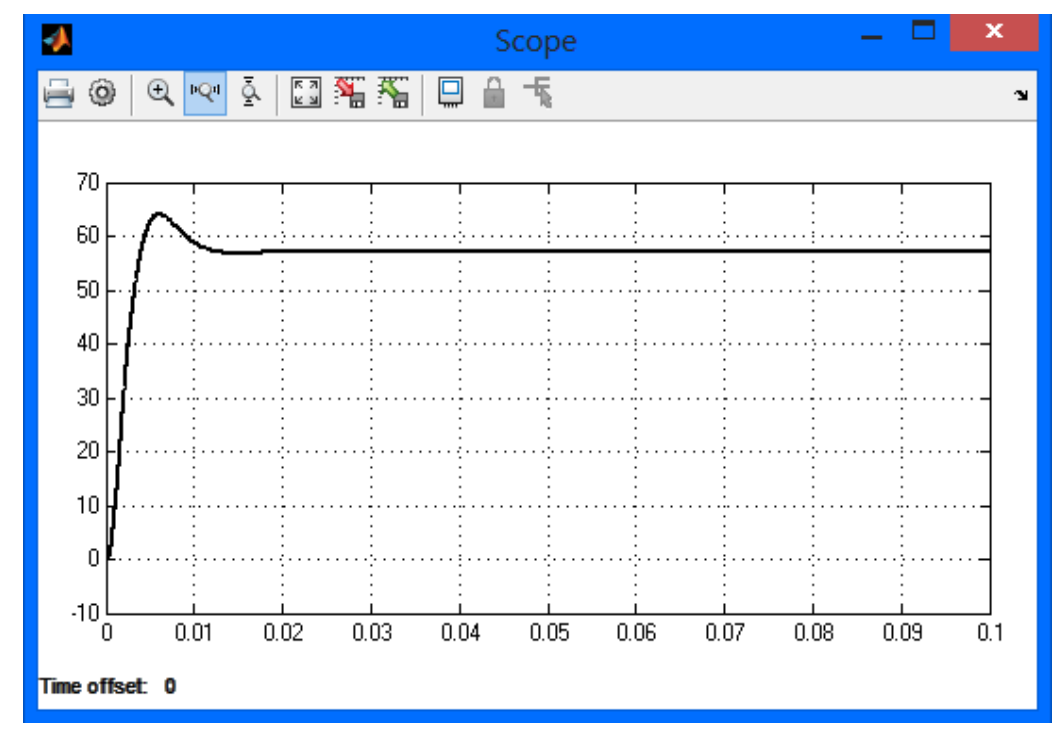

Figure 5 Output Voltage of Quadratic Boost Converter with CLD Cell 
Quadratic Boost Converter with CLD Cell for Solar Lighting Applications

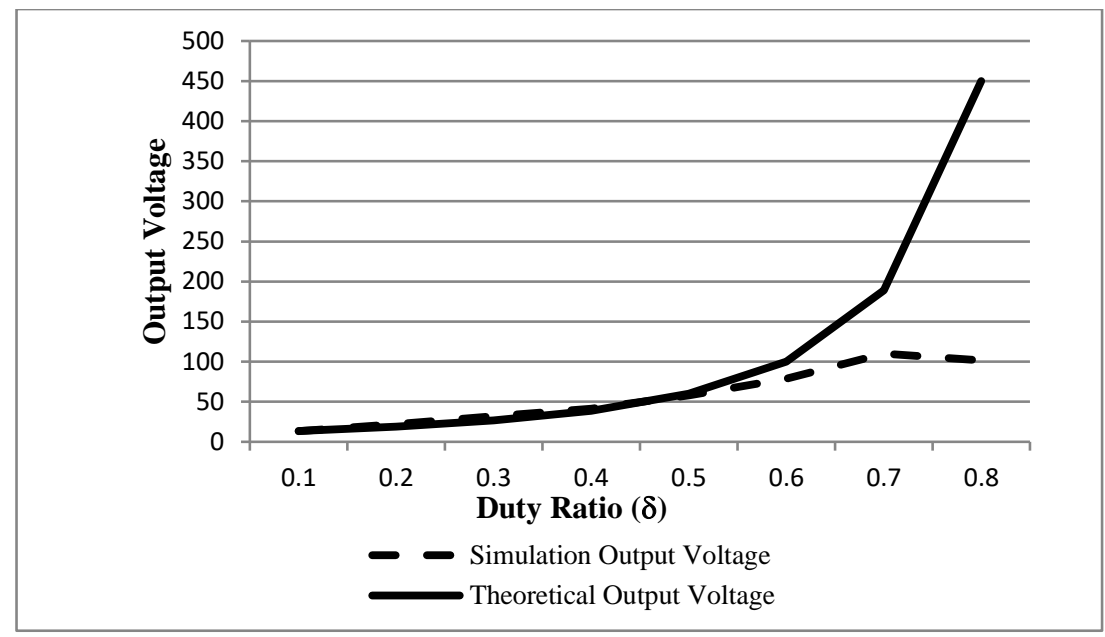

Figure 6 Comparison of Theoretical and Simulation Output Voltage

Table 1 Comparison between Theoretical Output Voltage and Simulation Output Voltage of Quadratic Boost Converter with CLD Cell

\begin{tabular}{|c|c|c|c|c|c|}
\hline S. No & $\begin{array}{c}\text { Duty cycle } \\
(\boldsymbol{\delta})\end{array}$ & $\begin{array}{c}\text { Theoretical } \\
\text { Output Voltage } \\
(\mathbf{V})\end{array}$ & $\begin{array}{c}\text { Theoretical } \\
\text { Output Current } \\
(\mathbf{I})\end{array}$ & $\begin{array}{c}\text { Simulation } \\
\text { Output Voltage } \\
(\mathbf{V})\end{array}$ & $\begin{array}{c}\text { Simulation } \\
\text { Output Current } \\
(\mathbf{I})\end{array}$ \\
\hline 1 & 0.1 & 13.5 & 0.135 & 13.31 & 0.1331 \\
\hline 2 & 0.3 & 26.5 & 0.265 & 28.32 & 0.2832 \\
\hline 3 & 0.5 & 60 & 0.60 & 57.7 & 0.577 \\
\hline 4 & 0.7 & 188.9 & 1.889 & 110 & 1.10 \\
\hline 5 & 0.9 & 190 & 1.90 & 139.39 & 1.3939 \\
\hline
\end{tabular}

\subsection{Voltage Stress Calculation}

The quadratic boost converter with CLD cell has reduce switching stress on the switches as already mentioned. The stress on the switch (MOSFET) and diodes ( $\left.\mathrm{D}_{1}, \mathrm{D}_{2}, \mathrm{D}_{3} \& \mathrm{D}_{4}\right)$ can be calculated from the equation 8 and equation 9 respectively.

$$
\begin{aligned}
& V_{S w-\text { Stress }}=\frac{V_{O}}{(1+\delta)} \\
& V_{D 1-\text { Stress }}=\frac{(1-\delta) V_{O}}{(1+\delta)}
\end{aligned}
$$

The voltage stress in the switch from theoretical value is $40 \mathrm{~V}$ and the simulation output of voltage stress on the switch is $40 \mathrm{~V}$ shown in figure 7 .

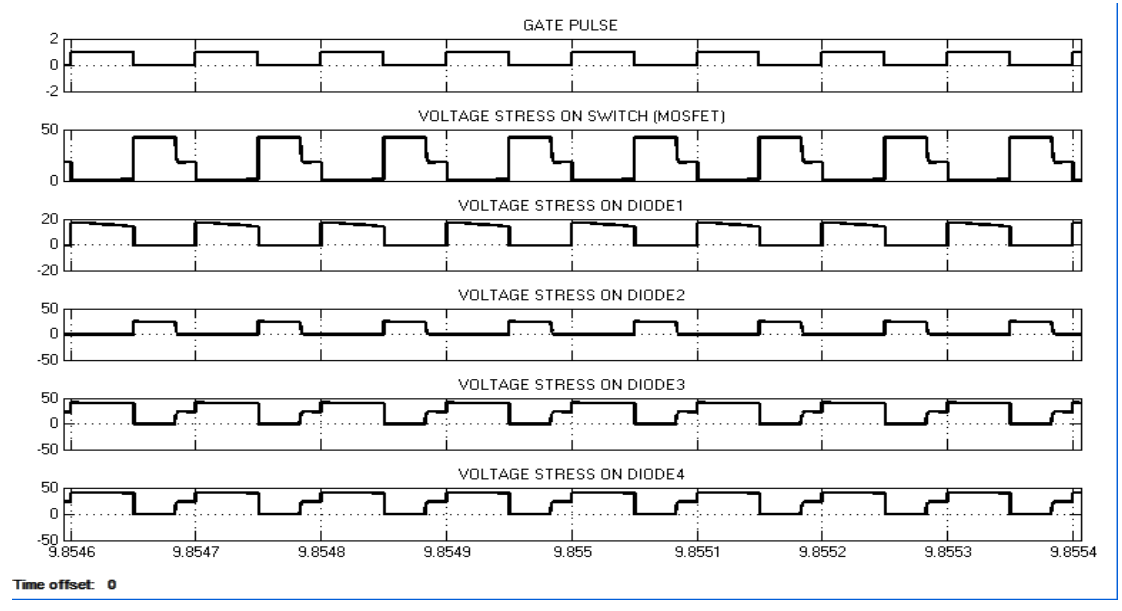

Figure 7 Voltage Stress in Switch and all Diodes 


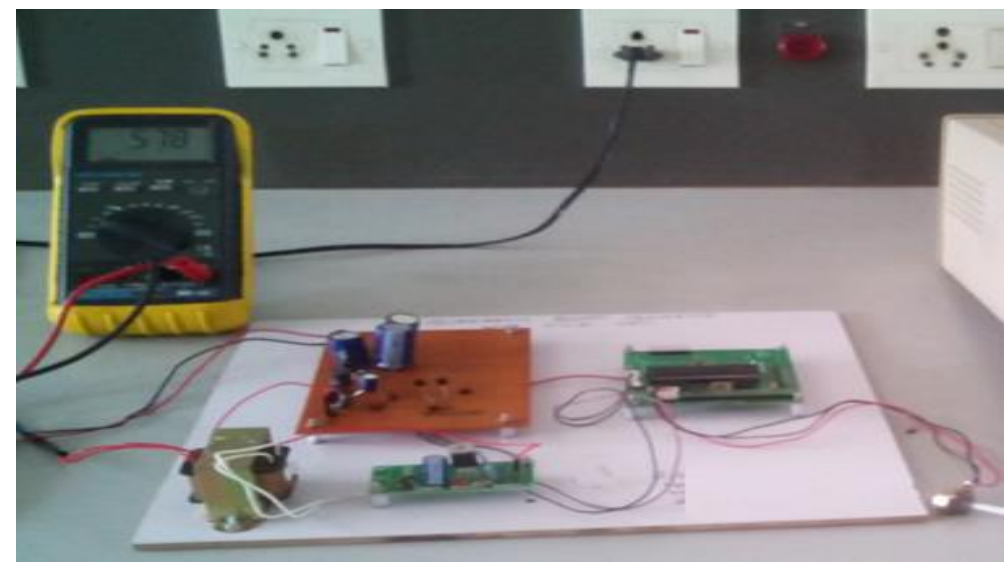

Figure 8 Input Voltage of Quadratic Boost Converter with CLD cell

\section{HARWARE IMPLEMENTATION AND RESULTS}

The Quadratic Boost Converter with CLD cell is implemented and results are compared with the simulation outputs. PIC16F877A microcontroller based control circuit is used for providing gate pulses to the switch (S). The Input voltage (5V) of Quadratic Boost Converter with CLD Cell is shown in figure 8. The Gate Pulse $(\delta)$ waveform measured from DSO for MOSFET of Quadratic Boost Converter with CLD Cell is shown in figure 9 for the duty ratio $(\delta)$ value set to 0.3. The output voltage of Quadratic Boost Converter with CLD cell is represented in figure 10 .

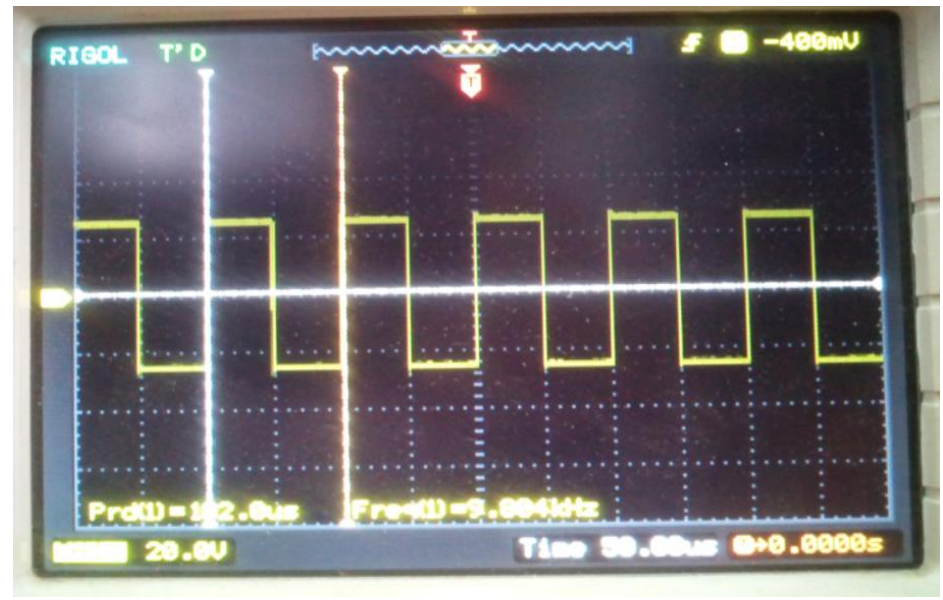

Figure 9 Gate Pulse for MOSFET Switch

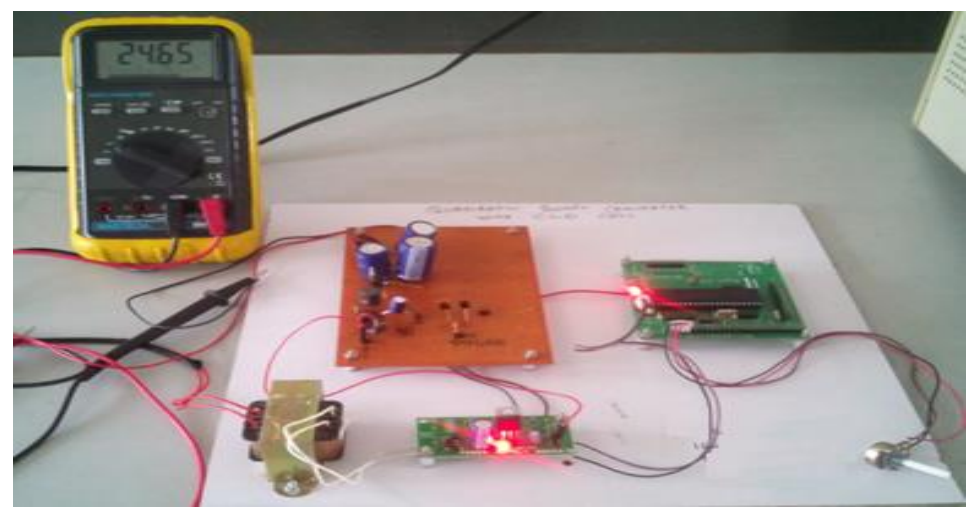

Figure 10 Output Voltage of Quadratic Boost Converter with CLD cell 
The performance analysis of the proposed converter is validated from the voltage gain, voltage stress and efficiency. These parameters from the hardware setup is compared with the simulation for input voltage $\mathrm{V}_{\mathrm{S}}=5 \mathrm{~V}$, switching frequency $\mathrm{f}_{\mathrm{s}}=10 \mathrm{kHz}$, is shown in table 2 .

Table 2 Result comparison of Quadratic Boost Converter with CLD Cell

\begin{tabular}{|c|c|c|c|c|c|c|}
\hline \multirow{2}{*}{$\begin{array}{c}\text { Duty } \\
\text { ratio( } \delta)\end{array}$} & \multicolumn{2}{|c|}{ Output voltage $\left(\mathbf{V}_{\mathbf{o}}\right)$} & \multicolumn{2}{c|}{ Voltage Stress $\left(\mathbf{V}_{\mathbf{s}}\right)$} & \multicolumn{2}{c|}{ Efficiency $(\boldsymbol{\eta})$} \\
\cline { 2 - 7 } & $\begin{array}{c}\text { Simulation } \\
\text { Result }\end{array}$ & $\begin{array}{c}\text { Hardware } \\
\text { Result }\end{array}$ & $\begin{array}{c}\text { Simulation } \\
\text { Result }\end{array}$ & $\begin{array}{c}\text { Hardware } \\
\text { Result }\end{array}$ & $\begin{array}{c}\text { Simulation } \\
\text { Result }\end{array}$ & $\begin{array}{c}\text { Hardware } \\
\text { Result }\end{array}$ \\
\hline 0.3 & $28.32 \mathrm{~V}$ & $24.65 \mathrm{~V}$ & $21 \mathrm{~V}$ & $23 \mathrm{~V}$ & $80 \%$ & $76 \%$ \\
\hline
\end{tabular}

\section{CONCLUSIONS}

The quadratic boost converter with CLD cell is implemented and the comparison results shows that the proposed converter has high voltage gain compared to the traditional boost converters. It is also observed that the proposed converter has minimal voltage stress and it has high efficiency for small duty ratio. Quadratic boost converter with CLD topology offers higher voltage gain. This behavior allows the converter to operate in high switching frequency range, which is validated by the hardware results. So, the proposed quadratic boost converter with CLD cell topology is most suitable for solar PV applications. The CLD structure can incorporated with conventional boost converters and it can measure the performance and suitability for renewable energy sources. Also, the MPPT techniques and EMI analysis can be incorporated as further work with the proposed converter which make this converter more suited for solar PV applications.

\section{REFERENCES}

[1] Lopez-Santos, O., Martinez-Salamero, L., Garcia, G., Valderrama-Blavi, H., and SierraPolanco, T. 'Comparison of quadratic boost topologies operating under sliding-mode control'. Proc. Brazilian Power Electronics Conference, Gramado, 2013, pp. 66-71.

[2] Yuang-Shung, Tzu-Han Chou, Ling-Chia Yu, Hsin-Wei Huang, "Quadratic high gain boost converter for grid-tie PV system application", IEEE 2013 1st International Future Energy Electronics Conference (IFEEC), Dec 2013.

[3] Oswaldo López-Santos, Luis Martínez-Salamero, Germain García, Hugo Valderrama-Blavi, Daniel O. Mercuri, "Efficiency analysis of a sliding-mode controlled quadratic boost converter", IET Power Electronics, Nov 2013, Vol. 6, Iss. 2, pp. 364-373

[4] Edwing Alberto Moreno-Basaldúa, Catedrático Conacyt, Jorge Alberto Morales-Saldaña, Rodrigo Loera-Palomo, Catedrático Cona, "Design methodology for quadratic step-down dcdc converters based on non-cascading structures", IEEE 2016 13th International Conference on Power Electronics (CIEP), Aug 2016.

[5] Yuan-mao Ye, Ka Wai Eric Cheng, "Quadratic boost converter with low buffer capacitor stress,” IET Power Electronics, volume 7, issue 5, P. 1162-1170, 2014.

[6] K.H .Beena, Anish Benny, “ Analysis and Implementation of Quadratic Boost Converter for Nanogrid Applications”, IJAREEIE Vol. 4, Issue 7, July 2015.

[7] K.Tattiwong and C. Bunlaksananusorn, "Analysis, Design and Experimental Verification of a Quadratic Boost Converter”, Proceedings 10th IEEE Region conference TENCON,2014. 